\title{
INFERENCE MENGGUNAKAN FORWARD CHAINING PADA FOOD AFFORDABILITY
}

\author{
Adriyendi \\ IAIN Batusangkar, Indonesia \\ Jl. Sudirman No. 137 Kuburajo Limo Kaum, Batusangkar, Indonesia \\ Email: adriyendi@iainbatusangkar.ac.id
}

\begin{abstract}
Price, consumption, and production influence global food estimation. Food consumption and food production needs improving affordability, government policy and expert proposition in decision making. Expert have developed a scenario combining direct weather impact on key grain producing regions, indirect impact through crop pathogens, consequences for markets, and stock of global food. Global food production tended to increase, meanwhile consumption under production. In Indonesia, production is under consumption. It is anomaly by global situation and world condition. Government policy is tariff, export, and import. Export food influenced by price food commodity is not stable, meanwhile food import tended to increase because by national food consumption increasing demand. Government policy and expert proposition to modern society, need Expert System is increasing rapidly. In Artificial Intelligence, Expert System is a computer system that emulates the decision making ability of a human expert. There are two reasoning strategies in Expert System: Forward Chaining and Backward Chaining. The aim of this paper is to identify which reasoning strategy system (Forward Chaining). This paper focus on the concept of knowledge representation in Artificial Intelligence and implementing of Forward Chaining on Food Affordability. Food Affordability used to planning of food in the future. Finally, Inference using Forward Chaining on Food Affordability, the result it is good and can be used to planning and policy on national food.
\end{abstract}

Key words: Inference, Forward Chaining, Food Affordability, Price, Consumption, Production

\section{PENDAHULUAN}

Produksi pangan global cenderung meningkat, sementara konsumsi di bawah produksi. Estimasi tahun 2015-2016 berdasarkan USDA Report (Trade Policy Research and Development Agency, 2015), produksi pangan global sebesar 3.027,2 juta ton (total grains in million metrics ton), dan konsumsi pangan global sebesar 2.481,7 juta ton (total grains in million metrics ton).

Di Indonesia, produksi di bawah konsumsi. Ini artinya anomali dengan situasi global dan kondisi dunia. Faktor yang mempengaruhinya adalah cuaca, permintaan global, lahan pertanian terbatas, makro ekonomi (fluktuasi mata uang dollar US), kebijakan pemerintah, penyakit, biaya energi (harga minyak dunia dipengaruhi oleh biaya angkut distribusi minyak pada pasar global), konflik geopolitik, dan cadangan pangan menurun (rasio produksi terhadap rasio konsumsi adalah rendah) berdasarkan laporan CME Group (Trade Policy Research and Development Agency, 2015). Faktor cuaca yang mempengaruhi pangan diantaranya: banjir, gagal panen, penyakit tumbuhan, hujan lebat, longsor, dan kekacauan pangan.

Meningkatnya populasi penduduk kelas menengah di Tiongkok dan India (sekitar 60\% lebih dari penduduk dunia), ini artinya 
permintaan pangan meningkat. Permintaan pangan untuk menjaga keseimbangan produksi dan konsumsi agar ketersediaan pangan dapat diatasi. Ketersediaan pangan telah dikembangkan sedikitnya di $75 \%$ negara-negara di dunia.

Berdasarkan Economist Intelligence Unit Report (Trade Policy Research and Development Agency, 2015), korelasi antara Indeks Harga Energi dengan Indeks Harga Pangan sebesar 0.82, artinya harga energi sangat mempengaruhi harga pangan. Kebijakan pemerintah dalam hal tarif, ekspor dan impor khususnya bidang pangan nasional. Ekspor pangan dipengaruhi oleh harga komoditas pangan yang fluktuatif (tidak stabil), sementara impor pangan cenderung meningkat karena permintaan konsumsi pangan nasional naik. Untuk mengatasinya diperlukan analisis pakar dalam pengambilan kebijakan. Analisis pakar dalam menentukan inference untuk menghasilkan konklusi dengan mengggunakan Artificial Intelligence.

Dalam Artificial Intelligence (Thieme, 2013), Expert System (Sistem Pakar) merupakan sistem komputer untuk melakukan emulasi dalam pengambilan keputusan layaknya seorang pakar (ahli). Artificial Intelligence (Kecerdasan Buatan) sebagai sebuah aplikasi yang menggunakan kecerdasan atau keahlian seorang pakar untuk pemecahan masalah dikenal dengan istilah Knowledge Based System (Sistem Berbasis Pengetahuan) atau Rule Based System (Sistem Berbasis Aturan). Inference Engine (mesin inferensi) digunakan dalam Knowledge Based System (KBS) untuk proses inference (membuat kesimpulan). Pilihan strategis tergantung pada masalah yang dialami. Dengan asumsi bahwa masalah adalah solusi dari fakta-fakta (facts) untuk menghasilkan tujuan (goal). Arah tujuan dari solusi masalah adalah bagaimana pilihan dan perubahan setiap pilihan, diagnosa bagaimana menemukan efisiensi maksimum, membuat keputusan seperti layaknya seorang pakar.

KBS memiliki dua strategi utama yaitu: Forward Chaining (Runut Maju) dan Backward Chaining (Runut Mundur). Forward Chaining bekerja dari fakta menuju kesimpulan. Data pada Working Memory diuji terhadap kondisi dalam Rule Base (Basis Aturan). Ketika satu data pada fakta yang diuji tidak sesuai rule, maka silkus pengujian rule dilanjutkan sampai semua rule yang diuji memenuhi syarat dan menghasilkan kesimpulan.

Forward Chaining adalah pilihan terbaik (Negnevitsky, 2011), ketika semua fakta tersedia dengan pernyataan masalah. Ada kemungkinan banyak tujuan (goal), dan jumlah pola yang sedikit dari analisis data. Hal inilah yang membutuhkan sistem layaknya analisis pakar. Menemukan solusi dari fakta yang bervariasi, membuat kesimpulan dari berbagai pilihan dan kemungkinan menghasilkan solusi terbaik. Forward Chaining sebagai metode yang menghasilkan rangkaian urutan rule random dan kelihatannya tidak memiliki keterhubungan. Forward Chaining bekerja berdasarkan data-driven, otomatisasi, proses yang tanpa disadari seolah-olah tidak relevan untuk mencapai tujuan. Backward Chaining bekerja dari kesimpulan menuju fakta. Tujuan pada Working Memory diuji terhadap kesimpulan dalam Rule Base (Basis Aturan). Ketika tujuan yang diuji tidak sesuai kesimpulan, maka siklus pengujian tujuan dilanjutkan sampai kesimpulan yang diuji memenuhi syarat dan mencapai tujuan.

Backward Chaining adalah pilihan terbaik (Negnevitsky, 2011), bila tujuan yang diberikan ada dalam pernyataan masalah, atau konsultasi bisa dengan pantas dilakukan. Backward Chaining bekerja berdasarkan goaldriven, datang pada waktu yang tepat untuk solusi masalah. Kompleksitas dari Backward Chaining dapat menjadi linier dalam ukuran basis pengetahuan.

Berdasarkan paper (Sharma, 2012), pilihan antara Backward Chaining dan Forward Chaining dengan mempertimbangkan maksud dari rule, ukuran dataset, dan keperluan hasilnya (untuk apa dihasilkan).

Berdasarkan paper (Ajlan, 2015), perbandingan dalam identifikasi alasan pertimbangan apakah lebih mudah diterapkan (dapat dipakai), bila membuat penilaian dalam mengelola keahlian, khususnya bidang 
akademik. Rekomendasi bahwa pendekatan paling baik untuk Pengakuan Lulusan Sarjana adalah Forward Chaining.

Berdasarkan paper (Kapoor, 2016), fokus konsep dari representasi pengetahuan dalam Kecerdasan Buatan dan menekuni serta menggali perbandingan Backward Chaining dan Forward Chaining. Keduanya merupakan metode utama yang digunakan dalam mesin inferensi. Biasa juga digunakan untuk sistem keahlian dan sistem bisnis.

Berdasarkan paper (Kamley, 2016), Backward Chaining dan Forward Chaining adalah dua metode yang diusulkan untuk isu harga saham dan editor LISP 3.0 dalam desain sistem keahlian 'shell'. Perubahan data dan harga dipertimbangkan untuk model pengetahuan harga saham. Hasil penelitian menunjukkan bahwa Backward Chaining lebih baik dalam menampilkan hasilnya.

Berdasarkan paper (Haemmerle, 2014), kombinasi antara Backward dan Forward Chaining dalam CLP Framework, secara logika sebagai cara untuk mendapatkan keunggulan setiap tipe runutan. Sebuah 'kelas' dalam bahasa pemrograman yang keduanya digabung antara Constraint Logic dan Concurrent Constraint Programming. Asumsi bahwa pertemuan keduanya adalah penting dilakukan pilihan strategi dan logika bersandarkan pada kelengkapan bahasa pemrograman.

Berdasarkan paper (Kodavade, 2016), menerapkan Kecerdasan Buatan dan utama sekali untuk diagnosa kesalahan Sistem Berbasis Pengetahuan, yang diduga penyebab kegagalan pada papan sirkuit elektronik. Strategi yang diterapkan menggunakan Backward Chaining. Pengetahun diwakili dalam aturan struktur obyek dan cara inferensi memakai 'kelas'. Hasil dari pendekatan berorientasi obyek tersebut dibandingkan dan diagnosa kesalahan yang disahkan dengan keahlian dari pakar. Pada pendekatan berbasis aturan, semua aturan dipakai berurutan. Oleh karena itu, butuh waktu lebih banyak dalam diagnosa tipe kesalahan.

\section{METODE PENELITIAN}

\section{Proses Inference}

Proses inferensi dalam Sistem Berbasis Aturan adalah menggunakan inferensi deduktif. Aturan logika yang digunakan untuk mendapatkan pengetahuan baru dari pengetahuan yang sudah ada berdasarkan aturan. Mesin inferensi untuk basis aturan atau basis pengetahuan yang komponen dasarnya adalah:

Atribut: $X_{1}, X_{2}, X_{3}, \ldots X_{n} 1$

Kondisi: $C_{1}, C_{2}, C_{3}, \ldots C_{n} 2$

Aturan: $R_{1}, R_{2}, R_{3}, \ldots R_{n} 3$

Aksi: $A_{1}, A_{2}, A_{3}, \ldots A_{n} 4$

Atribut adalah variabel seperti dalam bahasa pemrograman dan punya tipe numerik atau string. Atribut juga sama halnya dalam Java programming, digunakan menyimpan nilai untuk digunakan kapan diperlukan. Nilainya dapat berupa Boolean (benar atau salah), teks, string atau angka. Atribut tidak perlu dideklarasikan atau dinyatakan, dan dapat memiliki bayak nilai pada waktu yang sama. Nama atribut dinyatakan dalam bentuk tanda kurung, bisa pakai spasi, dan peka terhadap huruf kapital. Atribut dapat memberikan nilai dalam kesimpulan sebuah aturan. Atribut juga memberikan nilai pada input dari pengguna. Atribut dapat dibandingkan dengan setiap nilai atau setiap premis (dasar pikiran) dengan menggunakan operator relasi. Aturan dinyatakan dalam bentuk:

IF <kondisi > THEN <aksi>

IF <premis > THEN <konklusi >

IF <premis 1>AND < premis 2> AND < premis ke- $n>$ THEN <kesimpulan>

IF <usulan p1>AND <usulan p2> adalah benar THEN <usulan $\mathrm{p} 3>$ adalah benar

Bagian aturan setelah IF dinamakan premis atau anteseden. Isinya digunakan sebagai 'sub-goals'. Bagian aturan setelah THEN dinamakan konsekuen atua konklusi. IF pada kondisi benar, maka THEN dieksekusi. Kondisi dan konklusi dalam aturan disusun proposisinya dengan operator AND, OR, dan NOT (Herrera, 2012).

Kondisi diikuti atribut dan operator logika AND. Logika AND dan OR dapat dipertimbangkan pada runut mundur (Backward Chaining), membaca aturan dari bawah ke atas. 
AND dan OR tidak bisa digunakan bersamaan dalam aturan yang sama. Logika adalah bentuk representasi pengetahuan yang paling tua. Proses logika adalah proses membentuk kesimpulan atau menarik suatu inferensi berdasarkan fakta yang telah ada. Input dari proses logika berupa premis atau fakta-fakta yang diakui kebenarannya sehingga dengan melakukan penalaran pada proses logika dapat dibentuk suatu inferensi atau kesimpulan yang benar juga. Ada dua penalaran yang dapat dilakukan untuk mendapat konklusi:

Penalaran deduktif:dimulai dari prinsip umum untuk mendapatkan konklusi yang lebih khusus.

Contoh:

Premis mayor: Jika punya uang, saya akan berangkat kuliah ke luar negeri

Premis minor: Hari ini saya tidak punya uang Konklusi: Hari ini saya tidak akan berangkat kuliah ke luar negeri

Penalaran induktif: dimulai dari faktafakta khusus untuk mendapatkan kesimpulan umum

Contoh:

Premis 1: Java Programing pelajaran yang sulit

Premis 2: VB Programming pelajaran yang sulit

Premis 3: C Programming pelajaran yang sulit Konklusi: Desktop Programming pelajaran yang sulit

Munculnya premis baru bisa mengakibatkan gugurnya konklusi yang sudah diperoleh.

Misalnya:

Premis 4: Android Programming pelajaran sulit

Premis tersebut menyebabkan:

Konklusi: Desktop Programming pelajaran sulit,

menjadi salah, karena:

Android Programming bukan merupakan bagian dari Desktop Programming,

Bila menggunakan penalaran induktif sangat dimungkinkan adanya ketidakpastian (bisa menggunakan metode Certainty Factor). Representasi pengetahuan berupa aplikasi aturan (rule): Anteseden, yaitu bagian yang mengekspresikan situasi atau premis (pernyataan berawalan IF) Konsekuen, yaitu bagian yang menyatakan suatu tindakan tertentu atau konklusi yang diterapkan jika suatu situasi atau premis bernilai benar (pernyataan berawalan THEN) Konsekuensi atau konklusi yang dinyatakan pada bagian THEN baru dinyatakan benar, jika bagian IF pada sistem tersebut juga benar atau sesuai dengan aturan tertentu. Basis pengetahuan mengandung pengetahuan untuk pemahaman, formulasi, dan penyelesaian masalah, disusun atas dua elemen dasar: Fakta: informasi tentang obyek dalam area permasalahan tertentu. Aturan: informasi tentang bagaimana memperoleh fakta baru dari fakta yang diketahui. Munculnya premis baru bisa mengakibatkan gugurnya konklusi yang sudah diperoleh, sehingga bila menggunakan penalaran induktif sangat dimungkinkan adanya ketidakpastian.

Representasi pengetahuan (Kamala, 2016) menggunakan aturan IF THEN yang dinyatakan dalam bentuk pernyataan dan tipe yang bisa lebih kompleks. Arsitektur dari Sistem Berbasis Aturan terdiri dari komponen: basis pengetahuan (isinya aturan dari ahli tentang pokok masalah), basis data (isinya kumpulan fakta tentang solusi masalah), mesin inferensi (isinya cara mengolah aturan dengan fakta untuk menemukan solusi), fasilitas penjelasan (isinya menyediakan keterangan cara menggunakan aturan) dan antarmuka pengguna (isinya layar komunikasi pengguna dan sistem).

Rekayasa pengetahuan merupakan proses untuk membuat Sistem Berbasis Aturan. Perkiraan masalah dan pemilihan tugas aturan yang tepat. Pemilihan aturan atau fakta yang tepat dan mengolah pengetahuan dengan perangkat lunak. Pengujian, cek kembali dan penggabungan aturan dan fakta ke dalam area kerja dalam sebuah sistem.

Representasi pengetahuan dan bagaimana membuat kesimpulan, telah dikembangkan 'shell' sebuah aplikasi untuk sistem keahlian (Anwar, 2016). Shell ini menjadi domain khusus basis pengetahuan menjadi sistem keahlian fungsional. Shell menyediakan antarmuka yang mudah dan bisa dikembangkan oleh sistem keahlian. Fungsi basis pengetahuan 
untuk menyimpan pengetahuan yang digunakan sistem, biasanya dengan pola logika formal.

Sistem inferensi mengartikan bahwa pengetahuan yang ada bisa digunakan untuk mendapatkan pengetahuan baru. Inferensi merupakan proses untuk menghasilkan informasi dari fakta yang diketahui atau diasumsikan. Inferensi adalah konklusi logis (logical conclusion) atau implikasi berdasarkan informasi yang tersedia dilakukan dalam suatu modul yang disebut Inference Engine (mesin inferensi). Faktor yang mempengaruhi pemilihan runut maju atau runut mundur dalam memilih metode penalaran.

Fakta tersebut yaitu:

Banyaknya keadaan awal dan tujuan. Jika jumlah keadaan awal lebih kecil daripada tujuan, maka digunakan penalaran maju. Sebaliknya jika jumlah tujuan lebih banyak daripada keadaan awal, maka dipilih penalaran mundur.

Rata-rata jumlah node yang dapat diraih langsung dari suatu node. Lebih baik dipilih yang jumlah node tiap cabangnya lebih sedikit. apakah program butuh menanyai user untuk melakukan justifikasi terhadap proses penalaran? Jika ya, maka alangkah baiknya jika dipilih arah yang lebih memudahkan user.

Bentuk kejadian yang memicu penyelesaian masalah. Jika kejadian itu berupa fakta baru, maka lebih baik dipilih penalaran maju. Namun jika kejadian itu berupa query, maka lebih baik digunakan penalaran mundur.

Inference Engine adalah bagian yang mencoba menggunakan informasi yang diberikan untuk menemukan obyek yang sesuai. Inference Engine mempunyai 2 kategori yaitu deterministik dan probabilistic (Ergado, 2016). Dasar untuk membentuk Inference Engine diantaranya: Forward Chaining, Backward Chaining dan Rule Value (merupakan pendahulu dari Forward Chaining dan Backward Chaining).

Kedua teknik penalaran (Forward Chaining dan Backward Chaining) dipengaruhi oleh tiga macam teknik penelusuran (Shi, 2016) yaitu:

Teknik Depth-First Search

Adalah teknik penelusuran data pada node-node secara vertical dan sudah terdefinisi, misalnya kiri ke kanan, keuntungan pencarian dengan teknik ini adalah bahwa penelurusan masalah dapat digali secara mendalam sampai di temukannya kapasitas suatu solusi yang optimal.

Kekurangan teknik penelesuran ini adalah membutuhkan waktu yang sangat lama untuk ruang lingkup masalah yang besar.

Teknik Breadth-First Search

Adalah teknik penelusuran data pada semua node dalam satu level atau salah satu tingkatan sebelum ke level atau tingkatan di bawahnya. Keuntungan pencarian daengan teknik ini adalah sama dengan Depth First Search, hanya saja penelusuran dengan teknik ini mempunyai nilai tambah, dimana semua node akan di cek secara menyeluruh pada setiap tingkatan node. Kekurangan teknik penelusuran ini terletak pada waktu yang dibutuhkan yang sangat lama. Apabila solusi berada dalam posisi node terakhir sehingga menjadi tidak efisien. Kekurangan dalam implementasi juga perlu di pertimbangkan, misalnya teknik penelusuran menjadi tidak interaktif antara suatu topik dengan topik yang lain atau harus melompat dari satu topik ke topik yang lain sebelum topik tersebut selesai di telusuri.

Teknik Best-First Search

Adalah teknik penelusuran yang menggunakan pengetahuan terhadap suatu masalah untuk melakukan panduan pencarian ke arah node tempat dimana solusi berada. Pencarian jenis ini dikenal juga sebagai model heuristik. Pendekatan yang dilakukan adalah mencari solusi yang terbaik berdasarkan pengetahuan yang dimiliki sehingga penelusuran dapat ditentukan harus di mulai dari mana dan bagaimana menggunakan proses terbaik untuk mencari solusi. Keuntungan jenis pencarian ini adalah mengurangi beban komputasi karena hanya solusi yang memberikan harapan saja yang diuji dan berhenti apabila solusi sudah mendekati yang terbaik. Ini merupakan model yang menyerupai teknik manusia mengambil solusi yang dihasilkan merupakan solusi yang mutlak benar.

Model Inference

Model Inference dilihat pada Gambar 1. 


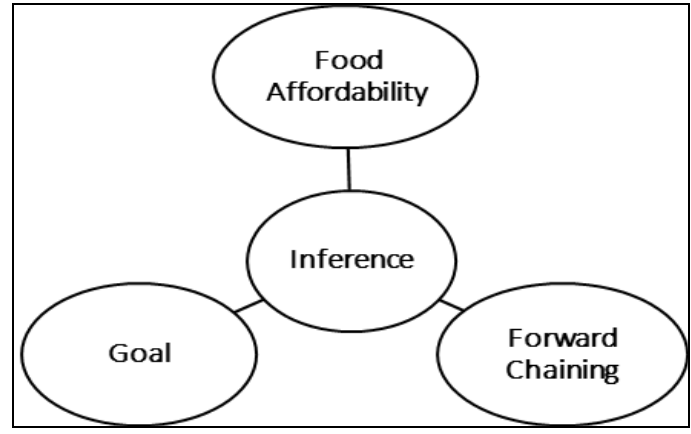

Gambar 1. Inference

Gambar 1 menampilkan Inference menggunakan metode Forward Chaining. Food Affordability sebagai tujuan berdasarkan analisa data. Goal adalah kesimpulan dalam inferensi.
Model Food Affordability

Food Affordability ditampilkan pada Gambar 2.

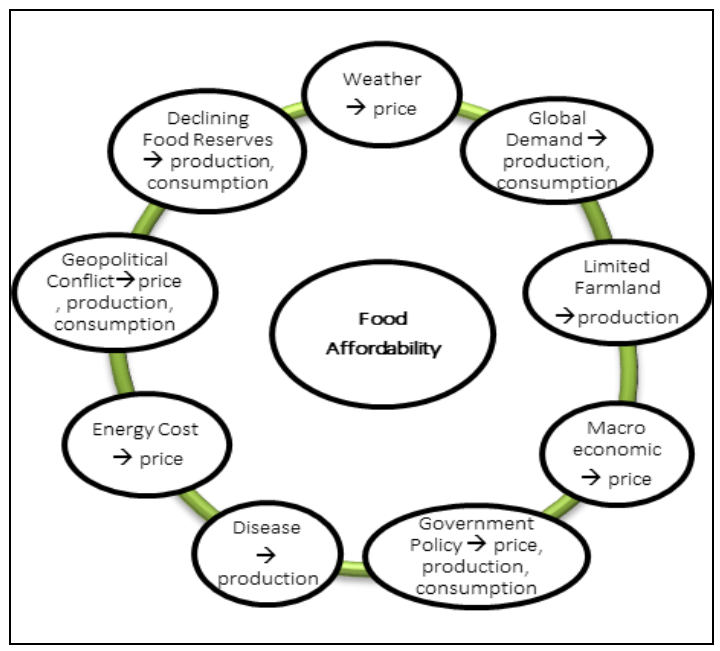

Gambar 2. Food Affordability

Gambar 2 menunjukkan bahwa Food Affordability dipengaruhi oleh banyak faktor. Harga, produksi dan konsumsi dominan dan sangat menentukan setiap faktor yang mempengaruhi Food Affordability.

\section{Metode Forward Chaining}

Forward Chaining (Runut Maju) digunakan pada Sistem Berbasis Aturan (Mzori, 2015), menggunakan himpunan aturan kondisi-aksi. Data digunakan untuk menentukan aturan mana yang bakal dijalankan, kemudian aturan tersebut dijalankan. Forward Chaining cocok digunakan untuk sintesa sistem, desain, konfigurasi, pengendalian dan prognosis (peramalan). Urutan langkah Forward Chaining dalam beberapa tahapan (Sharma, 2012) yaitu:

Tampilkan semua daftar premis.

User memilih premis yang dialami. 
Sistem mencari aturan yang premisnya terdiri dari premis-premis yang dipilih oleh user.

Sistem akan menampilkan konklusi dari aturan tersebut.

Untuk mengetahui apakah suatu fakta yang dialami oleh pengguna itu termasuk konklusi 1, konklusi 2, konklusi 3, atau konklusi 4 atau bahkan bukan salah satu dari konklusi tersebut. User diminta memasukkan premis-premis yang dialami. Sistem dapat memunculkan daftar premis yang mungkin sehingga user dapat memberikan umpan balik premis mana yang dialami dengan memilih satu atau beberapa dari daftar premis yang tersedia.

Sebuah aturan dalam bentuk umum:

\section{If $A$ and $B$ Then $C$}

Jika A dan B adalah fakta, dapat diterapkan aturan tersebut, tambahkan $\mathrm{C}$ ke basis data. Pencocokan fakta atau pernyataan dimulai dari bagian sebelah kiri dulu (IF dulu). Artinya penalaran dimulai dari fakta terlebih dahulu untuk menguji kebenaran hipotesis. Pelacakan dimulai dari keadaan awal (informasi atau fakta yang ada) dan kemudian dicoba untuk mencocokkan dengan tujuan yang diharapkan. Berdasarkan premis-premis yang dipilih maka sistem akan mencari aturan yang sesuai, sehingga akan diperoleh konklusinya.

Forward Chaining melakukan penalaran dari suatu masalah kepada solusinya. Jika klausa premis sesuai dengan situasi (bernilai true), maka proses bakal menyatakan konklusi. Pelacakan ini sangat baik jika bekerja dengan permasalahan yang dimulai dengan rekaman informasi awal dan ingin dicapai penyelesaian akhir, karena seluruh proses akan dikerjakan secara berurutan maju. Forward Chaining adalah data-driven karena inferensi dimulai dengan informasi yang tersedia dan baru konklusi diperoleh. Jika suatu aplikasi menghasilkan pohon keputusan (decision tree) yang lebar dan tidak dalam, maka gunakan Forward Chaining. Tipe sistem yang dapat dicari dengan Forward Chaining:

Sistem yang dipersentasikan dengan satu atau beberapa kondisi.

Untuk setiap kondisi, sistem mecari rule-rule dalam knowledge base untuk rule- rule yang berkorespondensi dengan kondisi dalam bagian IF.

Setiap rule dapat menghasilkan kondisi baru dari konklusi yang diminta pada bagian THEN. Kondisi baru ini ditambahkan ke kondisi lain yang sudah ada.

Setiap kondisi yang ditambahkan ke sistem akan diproses.

Jika ditemui suatu kondisi baru dari konklusi yang diminta, sistem akan kembali ke langkah b dan mencari rule-rule dalam knowledge base kembali.

Jika tidak ada konklusi baru, sesi ini berakhir.

Forward Chaining sebagai data-driven karena inference engine menggunakan informasi yang ditentukan oleh user untuk memindahkan ke seluruh jaringan dari logika 'AND' dan 'OR' sampai sebuah terminal ditentukan sebagai obyek. Bila inference engine tidak dapat menentukan obyek, maka akan meminta informasi lain. Aturan (Rule) dimana menentukan obyek, membentuk path (lintasan) yang mengarah ke obyek.

Oleh karena itu, hanya satu cara untuk mencapai satu obyek adalah memenuhi semua aturan. Forward Chaining menggunakan Breadth First Search Algorithm (Babu, 2016).

\section{Goal}

Untuk menentukan goal (tujuan), digunakan logika pada basis pengetahuan yang dapat menghasilkan pengetahuan baru dan bisa dipakai dalam pengambilan keputusan. Goal dapat berbentuk pertanyaan atau query, untuk memperoleh jawaban. Goal dicari untuk menentukan sebuah jawaban dari query, bisa dengan format Boolean (benar atau salah) dan bisa menjadi query complex.

Contoh sederhana (Hestiningsih, 2015) untuk penerapan Forward Chaining dan Backward Chaining dengan aturan (Rule/Ri):

R1: IF suku bunga turun THEN harga obligasi naik

R2: IF suku bunga naik THEN harga obligasi turun

R3: IF suku bunga tidak berubah THEN harga obligasi tidakberubah

R4: IF dolar naik THEN suku bunga turunR5: IF dolar turun THEN suku bunga naik 


\section{R6: IF harga obligasi turun THEN beli obligasi}

Apabila diketahui bahwa dolar turun, maka untuk memutuskan apakah akan membeli obligasi atau tidak, dapat ditunjukkan sebagai berikut:

Forward Chaining

Dari fakta dolar turun, berdasarkan R5, diperoleh konklusi suku bunga naik.

Dari R2 suku bunga naik menyebabkan harga obligasi turun.

Dengan R6, jika harga obligasi turun, maka kesimpulan yang diambil adalah membeli obligasi.

Backward Chaining

Dari solusi yaitu membeli obligasi, dengan menggunakan $R 6$ diperoleh anteseden harga obligasi turun.

Dari $R 2$ dibuktikan harga obligasi turun bernilai benar, jika suku bunga naik bernilai benar.

Dari $R 5$ suku bunga naik bernilai memang bernilai benar, karena diketahui fakta dolar turun.

\section{HASIL DAN PEMBAHASAN}

\section{Metode Forward Chaining}

Proses inferensi pada Forward Chaining dngan komponen yaitu Aturan (Rule), Atribut (Attribute), Fakta (Fact), dan Aksi (Action).

Rule (R), Attribute (X), and Action (Ai):

If $[X$ dryness $(A)$ and $X$ winter $(B)$ and $X$ flood (C)] Then [X is bad weather (A1)]

Maksudnya: bila terjadi musim kering, musim dingin, dan banjir, maka hal tersebut merupakan faktor cuaca buruk.

If [X middle class population of Tiongkok is increase (D) and $\mathrm{X}$ middle class population of India is increase (E)] Then [X is high demand of global food (A2)] Maksudnya: bila pertumbuhan penduduk pada kelas menengah di Tiongkok dan bila pertumbuhan penduduk pada kelas menengah di India meningkat, maka terjadi permintaan pangan yang besar. Artinya Tiongkok dan India merupakan negara dengan penduduk terbesar sebagai mayoritas penduduk dunia.
If [X farmland to building property $(\mathrm{F})$ and $\mathrm{X}$ farmland to building infrastructure $(\mathrm{G})$ and $\mathrm{X}$ farmland be changed function became non-farming $(\mathrm{H})]$ Then [X is limited farmland (A3)]

Maksudnya: ketika lahan pertanian diubah menjadi lahan pembangunan property (hunian bangunan perumahan) dan lahan alih fungsi menjadi infrastruktur gedung pusat bisnis, dan sentra industri, maka lahan pertanian berganti menjadi lahan non pertanian, kesulitan mengembangkan dan memperluas jumlah lahan pertanian.

If [X USD strong (I) and X IDR weak $(\mathrm{J})]$ Then [X is macroeconomic factors (A4)]

Maksudnya: saat mata uang didominasi oleh penggunaan dollar dan nilai rupiah menurun, maka hal tersebut menjadi faktor makro ekonomi global.

If [X domestic tariff $(\mathrm{K})$ and $\mathrm{X}$ market price (L)] Then [X is government policy (A5)]

Maksudnya: kebijakan tarif dan aturan dalam negeri dalam penentuan harga di pasar uang, maka intervensi pemerintah sangat penting dan diperlukan kontrol kuat dan ketat dalam penetapan harga pasar pada semua komoditas utama sangat menentukan.

If $[X$ plant disease $(M)$ and $X$ paddy parched $(\mathrm{N})]$ Then [X is un-harvest (A6)]

Maksudnya: saatpenyakit dan gangguan tanaman serta tumbuhan menjadi rusak terjadi pada padi (penghasil beras sebagai makanan pokok), maka hal tersebut menjadi faktor gagal panen.

If $[X$ oil prices $(O)$ and $X$ freight out cost $(\mathrm{P})]$ Then [X is high cost of energy (A7)]

Maksudnya: harga minyak dunia naik dan biaya transportasi meningkat (BBM naik), maka hal tersebut menimbulkan ekonomi biaya tinggi.

If $[X$ disturbance $(\mathrm{Q})$ and $\mathrm{X}$ local conflict (R)] Then [X is geopolitical conflict (A8)]

Maksudnya: bila terjadi kerusuhan, aksi massa, konflik lokal, maka akan menimbulkan gangguan keamanan dan mengganggu kestabilan politik. Gangguan tersebut mempengaruhi ekonomi nasional. 
If $[\mathrm{X}$ food production ratio is low $(\mathrm{S})$ and $\mathrm{X}$ food consumption ratio is high $(\mathrm{T})]$ Then $[\mathrm{X}$ is declining food reserves(A9)]

Maksudnya: bila ratio produksi pangan rendah dan ratio konsumsi tinggi, maka cadangan pangan berkurang, terjadi penurunan daya dukung pangan, rentan ketahanan dan keamanan pangan nasional.

Fact $(\mathrm{F})$ and Conclusion $(\mathrm{C})$ :

If $[X$ bad weather (A1) and $\mathrm{X}$ macroeconomic factors (A4) and $\mathrm{X}$ high cost of energy (A7) Then [X is price $(\mathrm{C} 1)]$

Maksudnya: jika terjadi cuaca buruk dan faktor makro ekonomi melemah, maka muncullah ekonomi biaya tinggi.

If [X limited farmland (A3) and $\mathrm{X}$ unharvest (A6) Then [X is production (C2)]

Maksudnya: jika lahan pertanian terbatas dan gagal panen, maka produksi pangan berkurang.
If $[\mathrm{X}$ government policy (A5) and $\mathrm{X}$ geopolitical conflict (A8) Then [X is price, production and consumption (C3)]

Maksudnya: jika kebijakan pemerintah lemah dan terjadi gangguan politik lokal, maka signikan mempengaruhi harga, produksi dan konsumsi.

If [X high demand of global food (A2) and $\mathrm{X}$ declining food reserves (A9) Then [X is production and consumption (C4)]

Maksudnya: jika permintaan pangan tinggi dan terjadi kekurangan cadangan pangan, maka dominan mempengaruhi produksi dan konsumsi.

Goal

Goal: [Price, production and consumption prerequisite food affordability (Goal)]

Maksudnya: harga, produksi, konsumsi menjadi prasyarat ketersediaan pangan.

Tabel 1. Rule Knowledge Base

\begin{tabular}{ccc}
\hline Rule & Knowledge Base & Action \\
\hline R1 & If A and B and C & A1 \\
R2 & If D and E & A2 \\
R3 & If $\mathrm{F}$ and $\mathrm{G}$ and $\mathrm{H}$ & $\mathrm{A} 3$ \\
R4 & If I and J & $\mathrm{A} 4$ \\
R5 & If $\mathrm{K}$ and $\mathrm{L}$ & $\mathrm{A} 5$ \\
R6 & If $\mathrm{M}$ and N & $\mathrm{A} 6$ \\
R7 & If O and P & $\mathrm{A} 7$ \\
R8 & If Q and R & $\mathrm{A} 8$ \\
R9 & If S and T & $\mathrm{A} 9$ \\
F1 & If A1 and A4 and A7 & $\mathrm{C} 1$ \\
F2 & If A3 and A6 & $\mathrm{C} 2$ \\
F3 & If A5 and A8 & $\mathrm{C} 3$ \\
F4 & If A2 and A9 & $\mathrm{C} 4$ \\
F5 & If C1 and C2 and C3 and C4 & Goal \\
\hline
\end{tabular}

Pada Tabel 1, Knowledge Base dengan Rule, Action, Fact, dan Goal yang menampilkan Rule (R1, R2, R3, .., R9) dengan Knowledge Base atau basis pengetahuan (If $\mathrm{A}$ and $\mathrm{B}$ and $\mathrm{C}$, If $\mathrm{D}$ and $\mathrm{E}, \ldots$, If $\mathrm{C} 1$ and $\mathrm{C} 2$ and C3 and C4) untuk mencapai Goal dengan Fakta (F1, F2, F3, F4) Fakta merupakan pengetahuan baru berdasarkan proses inferensi.

Goal
Inferensi dilakukan dengan tujuan adalah food affordability (ketersediaan pangan). Price (harga), production (produksi), dan consumption (konsumsi) merupakan faktor penentu ketersediaan pangan. Harga tergantung pada cuaca, konsumsi tergantung pada permintaan global, dan produksi tergantung keterbatasan lahan pertanian. Harga tergantung faktor ekonomi makro. Harga, produksi, 
konsumsi tergantung pada kebijakan pemerintah.

Produksi tergantung pada pengaruh penyakit (hama-tanaman). Harga tergantung pada biaya energi (harga minyak dunia dan biaya distribusi/transportasi). Harga dan produksi tergantung pada kondisi geopolitik dan konflik. Produksi dan konsumsi tergantung pada menurunnya cadangan pangan global.
Faktor cuaca, faktor permintaan pangan global, faktor lahan pertanian terbatas, faktor ekonomi makro, faktor kebijakan pemerintah, faktor penyakit, faktor biaya energi, faktor konflik geopolitik, dan faktor menurunnya cadangan pangan menjadi fakor pemicu yang sangat dipengaruhi oleh harga, produksi dan konsumsi pangan.

\begin{tabular}{|c|c|c|c|c|c|}
\hline & ID-A & \multicolumn{2}{|l|}{$x i$} & & ct $\quad$ \\
\hline \multicolumn{4}{|c|}{1 Dryness } & A & \\
\hline \multicolumn{4}{|c|}{2 Winter } & B & \\
\hline \multicolumn{4}{|c|}{3 Flood } & C & \\
\hline \multicolumn{4}{|c|}{4 Middle class population of Tiongkok is increase } & $D$ & \\
\hline \multicolumn{4}{|c|}{5 Middle class population of India is increase } & E & \\
\hline \multicolumn{4}{|c|}{6 Farmland to building property } & $F$ & \\
\hline \multicolumn{4}{|c|}{7 Farmland to building infrastructure } & G & \\
\hline \multicolumn{4}{|c|}{8 Farmland be changed function became non-farming } & H & \\
\hline \multicolumn{4}{|c|}{ g USD strong } & 1 & \\
\hline \multicolumn{4}{|c|}{10 IDR weak } & J & \\
\hline \multicolumn{4}{|c|}{11 Domestictariff } & K & \\
\hline \multicolumn{4}{|c|}{12 Market prices } & L & \\
\hline \multicolumn{4}{|c|}{13 Plant desease } & M & \\
\hline \multicolumn{4}{|c|}{14 Paddy parched } & N & \\
\hline \multicolumn{4}{|c|}{15 oil prices } & 0 & \\
\hline \multicolumn{4}{|c|}{16 Freight out cost } & p & \\
\hline \multicolumn{4}{|c|}{17 Disturbance } & Q & \\
\hline \multicolumn{4}{|c|}{18 Local conflict } & $R$ & \\
\hline \multicolumn{4}{|c|}{19 Food production is low } & $S$ & \\
\hline \multicolumn{4}{|c|}{20 Food consumption is high } & T & \\
\hline \multicolumn{4}{|c|}{ (New) } & & \\
\hline \multicolumn{4}{|c|}{ 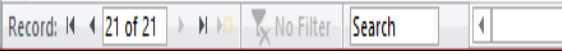 } & & $t$ \\
\hline
\end{tabular}

Gambar 3. Desain Tabel Atribut

Gambar 3 menjelaskan tentang desain atribut sebanyak 20 dengan Act (A, B, C, D, E, F, G, H, I, J, K, L, M, N, O, P, Q, R, S, dan $\mathrm{T})$. Atribut ini berfungsi sebagai indikator yang akan digunakan dalam proses inferensi.
Indikator tersebut akan dipilih lalu diproses dalam menemukan knowledge untuk menentukan category dan criteria dalam proses inferensi 


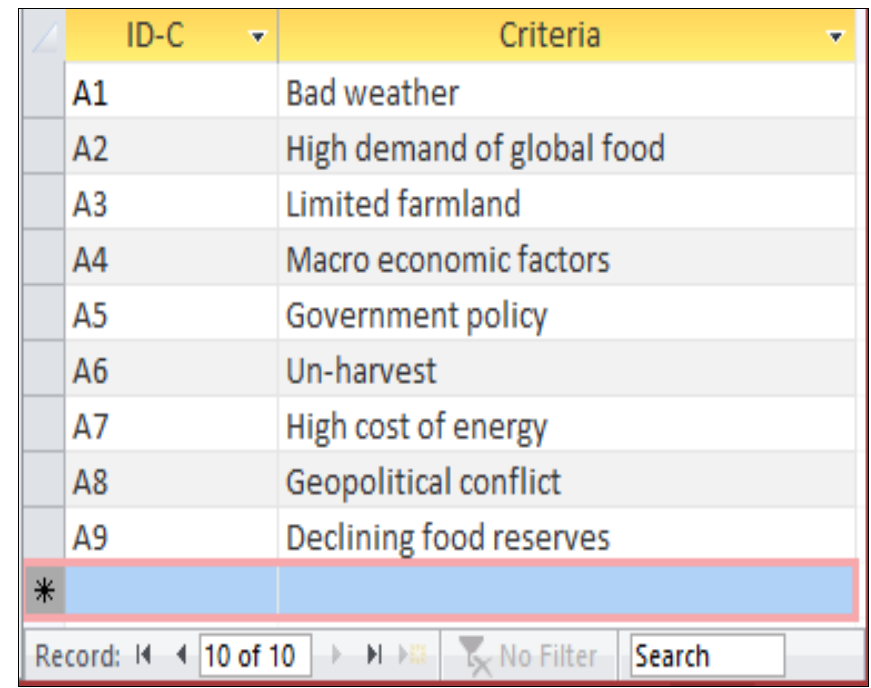

Gambar 4. Desain Tabel Kriteria

Gambar 4 menjelaskan tentang criteria untuk digunakan dalam menentukan rule.

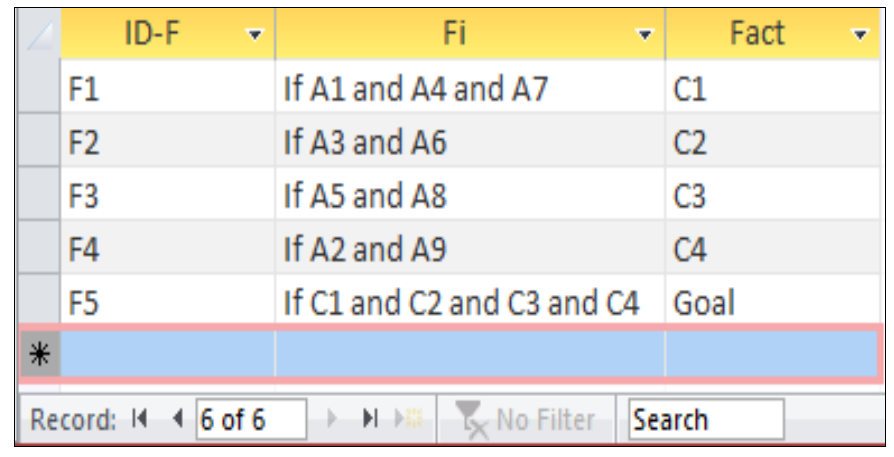

Gambar 5. Desain Tabel Fakta

Gambar 5 menampilkan fact yang digunakan untuk menemukan criteria dalam mencapai goal. Fakta baru (new fact) yang dihasilkan digunakan untuk menghasilkan goal. 


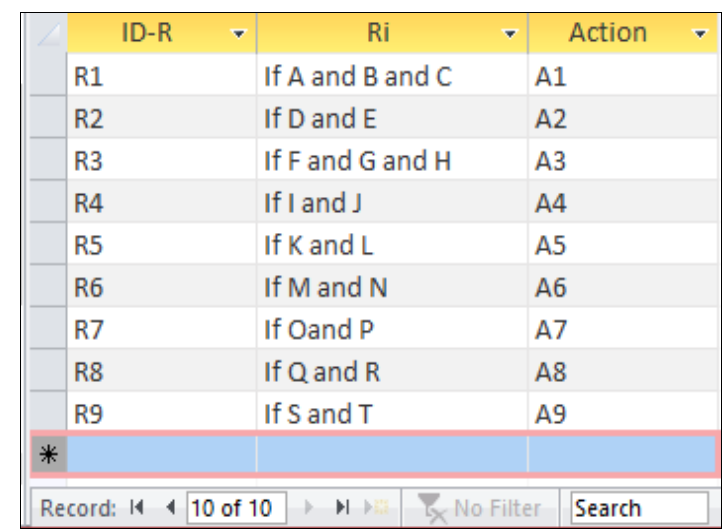

Gambar 6. Desain Tabel Aturan

Gambar 6 menunjukkan proses inferensi berdasarkan rule (R1, R2, R3, R4, R5, R6, R7, R8, dan R9) dan menentukan action (A1, A2, A3, A4, A5, A6, A7, A8, dan A9).

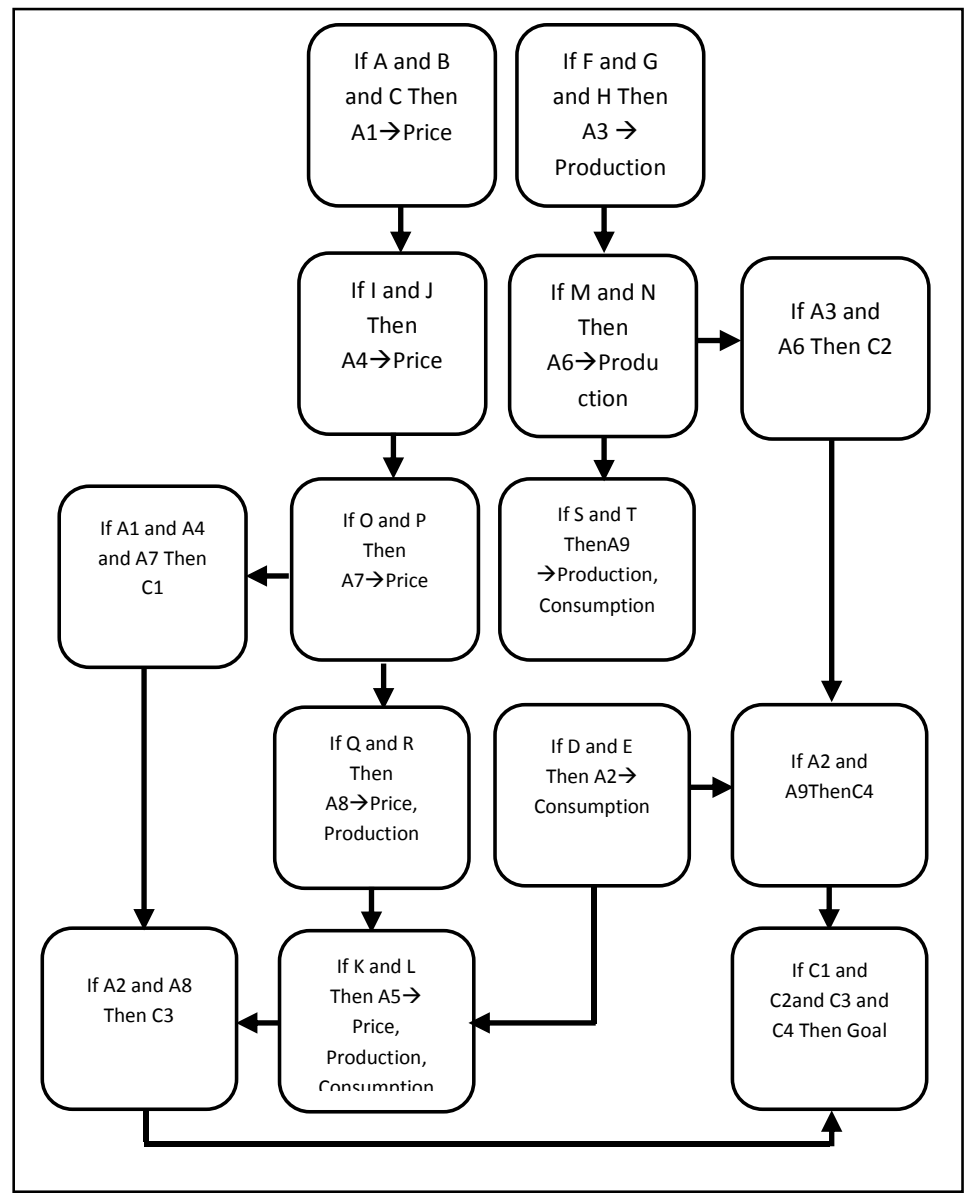

Gambar 7. Inference Forward Chaining 
Pada Gambar 7, proses Inferensi (inference) ditampilkan berdasarkan sumber data (tabel dalam basis data) yang ditampilkan pada Gambar 3, Gambar 4, Gambar 5, dan Gambar 6.

Inferensi ditentukan oleh tujuan, fakta, aturan, ujicoba aturan, jumlah data, ketersediaan informasi, pencarian fakta, penggerak data, sebab akibat argumentasi, hipotesa, bagaimana menemukan fakta, bagaimana mencari solusi, fokus masalah, keterangan penjelasan, bentuk inferensi, pernyataan kondisi awal atau inisiasi tujuan. Inferensi juga ditentukan oleh sedikit atau banyaknya query, bagaimana memulai proses inferensi, pengujian, cepat atau lambatnya proses inferensi, luas atau sempitnya ruang pencarian fakta. Inferensi juga dipengaruhi oleh efisiensi proses, tujuan dengan sedikit atau banyak konklusi, praktis atau tidak dalam penerapannya, patut, layak atau pantas, tipe pencarian fakta, lajur, jalur data dan subyek yang menentukan proses inferensi.

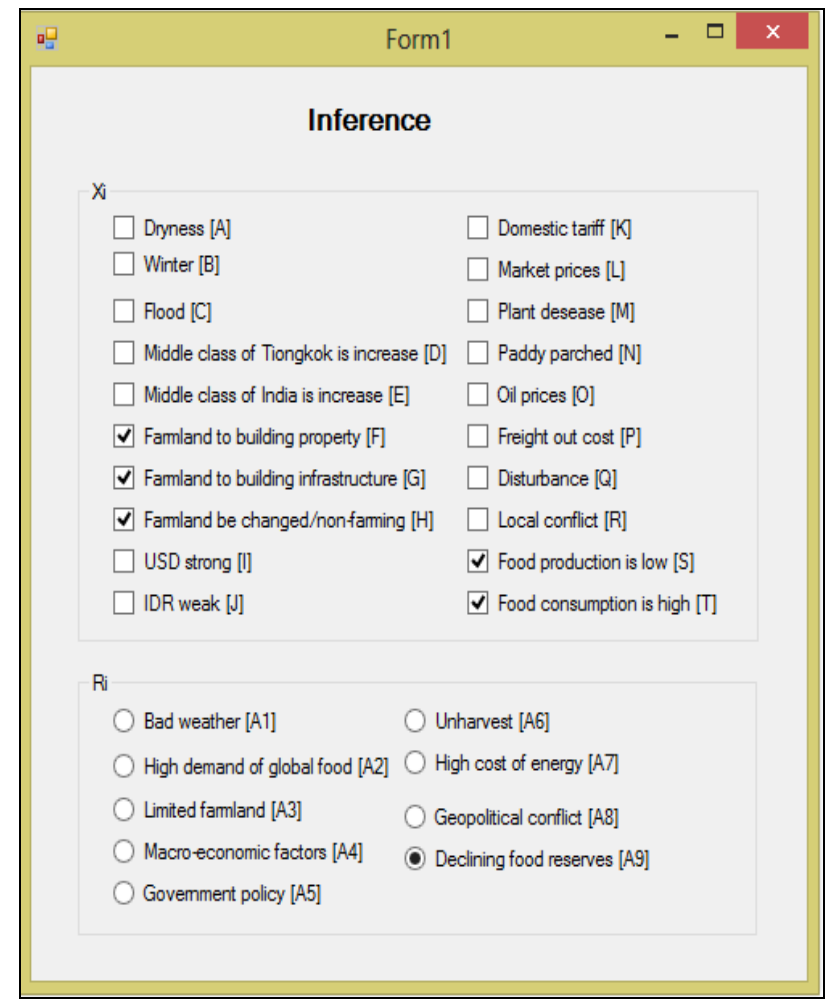

Gambar 8. User Interface

Gambar 8 menampilkan User Interface sebagai input nilai atribut (Xi) dan aturan (Ri). 


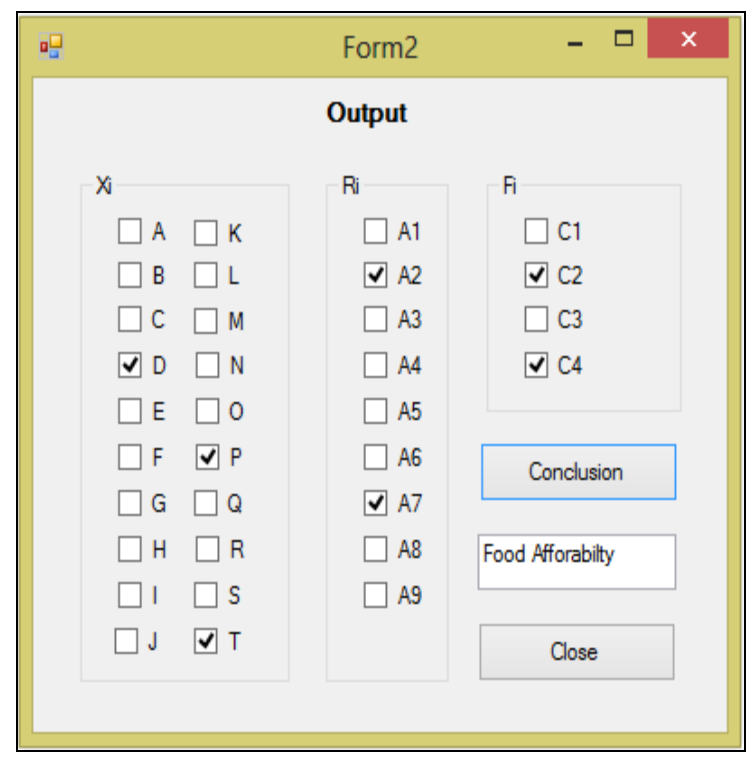

Gambar 9. Output

Gambar 9 menampilkan Output sebagai hasil dari proses inferensi. Hasil tersebut diperoleh dari Input (Xi, Ri, dan Fi).

\section{KESIMPULAN}

Inferensi menggunakan Forward Chaining dengan tujuan untuk menemukan solusi dari masalah ketersediaan pangan. Ketersediaan pangan ditentukan oleh faktor harga, produksi, dan konsumsi sebagai prasyarat dalam perencanaan pangan. Ketersediaan pangan digunakan untuk perencanaan pangan masa depan. Disimpulkan bahwa pendekatan pada inference untuk ketersediaan pangan menggunakan Forward Chaining dapat dilakukan dan berhasil dengan baik. Riset selanjutnya, Sistem Berbasis Pengetahuan pada Food Affordability dengan menggunakan Certainty Factor dan Case Base Reasoning.

\section{DAFTAR KEPUSTAKAAN}

\section{Ajlan A. 2015. The Comparison Between Forward And Backward Chaining, International Journal of Machine}

Learning and Computing, vol. 5, no. 2, pp. 106-113.

Anwar S B. 2016. Using Expert Systems for Fault Management in Electrical Power Systems, Global Journal of Engineering Science and Researches, vol. 3, no. 2, pp. 35-40.

Babu S, PK dan Perumal GJ. 2016. The Development of Expert-System for Corrosion Protection of Ship Structures, IOSR Journal of Mechanical and Civil Engineering, pp. 56-63.

Ergado AA. 2016. Self Learning Computer Trouble Shooting Expert System, International Journal of Artificial Intelligence \& Applications, vol. 7, no. 1, pp. 45-58.

Haemmerle R. 2014. On Combining Backward and Forward Chaining in Constraint Logic Programming, PPDP 14: ACM, pp. 1-12.

Herrera JFA. 2012. Integer Programming Applied to Rule Based Systems, Procedia Computer Science: Elsevier, vol. 9, pp. 1553-1562.

Hestiningsih \& Idhawati, 2015. Artificial Intelligence, e-book, pp. 1-45. 
Kamala SPR \& Justus S. 2016. Towards Mork: Model For Representing Knowledge, International Journal Modern Education and Computer Science, vol. 8, no. 3, pp. 45-53.

Kamley S, S Jaloree, dan RS Thakur. 2016. Performance Comparison between Forward and Backward Chaining Rule Based Expert System Approaches Over Global Stock Exchanges, International Journal of Computer Science and Information Security, vol. 14, no. 3, pp. 74-81.

Kapoor N dan N Bahl. 2016. Comparative Study of Forward and Backward Chaining In Artificial Intelligence, International Journal of Engineering and Computer Science, vol. 5, iss. 4, pp.16239-16242.

Kodavade DV. 2016. Knowledge Based Approach for Fault Diagnosis in Electronic Circuit Boards, International Journal of Control and Automation, vol. 9, no.1, pp. 293-308.
Mzori BHS. 2015. Forward and Backward Chaining Techniques of Reasoning in Rule-Based Systems, thesis, Eastern Mediterranean University, pp. 1-53.

Negnevitsky M. 2011. Artificial Intelligence: A Guide to Intelligent Systems (3rd Edition), Addison Wesley.

Sharma T, N Tiwari dan D Kelkar. 2012. Study Of Difference Between Forward And Backward Reasoning, International Journal of Emerging Technology and Advanced Engineering, vol. 2, iss.10, pp. 271-273.

Shi H, K Maly dan D Chong. 2016. Backward Chaining Ontology Reasoning Systems With Custom Rules, International World Wide Web Conference Committee, ACM, pp. 381-386.

Thieme LS. 2013. Artificial Intelligence: First Order Logic Inference, Course on Artificial Intelligence, pp. 1-20.

Trade Policy Research and Development Agency, 2015. Pre-Outlook Economy of Farming 2016, The Ministry of Trade of the Republic of Indonesia. 